\title{
Productivity of Four Intensively Managed Grasses under Grazing Management in the Humid Hill Region of Puerto Rico, ${ }^{1,2}$
}

\begin{abstract}
José Rodriguez, Edmundo Rivera and José Vicente-Chandler ${ }^{3}$
ABSTRACT

Four grasses on intensively managed, grazed $10 \times 10 \mathrm{~m}$ plots produced similar yields of dry forage expressed in $\mathrm{kg} / \mathrm{ha} / \mathrm{yr}$ as follows: Pangola10,330; Signal-9,900; Tanner-11,030; and Transvala-10,620. Yields of Signal, Tanner and Congo grasses were comparable to yields obtained in a large scale grazing experiment nearby, a fact which confirmed the validity of the small experimental plot technique in determining yield potential of forage grasses under grazing management.
\end{abstract}

\section{INTRODUCTION}

Productivity of the best known tropical grasses has been determined in terms of carrying capacity and of milk or meat production in numerous grazing experiments conducted in the humid mountain region of Puerto Rico. Caro-Costas et al. (3) determined the productivity of intensively managed Guinea (Panicum maximum Jacq.), Pangola (Digitaria decumbens Stent), Napier (Pennisetum purpureum Schum), Para (Panicum purpurascens Raddi), and Molasses (Melinis minutiflora Beauv.) grass pastures on steep Humatas clay (Typic Tropohumults) in a 4-year grazing experiment near Orocovis. Para and Molasses grasses produced lower weight gains (an average of $712 \mathrm{~kg} / \mathrm{ha} / \mathrm{yr}$ ) and had a lower carrying capacity (an average of four 273-kg steers/ha) than did Pangola, Guinea and Napier grasses, which produced similar yields averaging $1,181 \mathrm{~kg}$ of weight gain/ha/yr with an average carrying capacity of 6.1273 -kg steers/ ha. Caro-Costas et al. (2) found that Star grass (Cynodon nlemfuensis) pastures, also on Humatas clay at Orocovis, outyielded those of Pangola grass, producing $1,514 \mathrm{~kg}$ of weight gain/ha/yr as compared with 1,062 $\mathrm{kg} / \mathrm{ha} / \mathrm{yr}$ for Pangola grass. The Star grass pastures had a carrying capacity of $7.4273-\mathrm{kg}$ steers/ha as compared with 6.5 for Pangola grass. Caro-Costas et al. (4) compared the productivity of intensively managed Congo (Brachiaria ruziziensis), Star, and Pangola grass pastures, also on Humatas clay near Orocovis. Star grass produced higher gains $(1,427$

'Manuscript submitted to Editorial Board March 1, 1979.

${ }^{2}$ Research conducted cooperatively between the Science and Education Administration, USDA and the College of Agricultural Sciences, Mayagüez Campus, University of Puerto Rico, Río Piedras, P.R.

${ }^{3}$ Assistant Agronomist, Agricultural Experiment Station, College of Agricultural Sciences, Mayagüez Campus, University of Puerto Rico, Agronomist, and soil ScientistLocation Leader, Science and Education Administration, USDA, respectively. 
$\mathrm{kg} / \mathrm{ha} / \mathrm{yr}$ ) than did Congo or Pangola grasses, with weight gains averaging $989 \mathrm{~kg} / \mathrm{ha} / \mathrm{yr}$. Star grass also had a higher carrying capacity (7.3 273-kg steer/ha) than did Congo or Pangola, which had an average carrying capacity of 5.2273 -kg steer/ha.

The productivity of Napier, Pangola, Guinea, Star, Congo and Para grasses under cutting management has been determined in numerous experiments carried out in Puerto Rico and summarized by VicenteChandler et al. $(7,8)$. The performance of these grasses under cutting was often different from that under grazing management.

Numerous grasses have been introduced in Puerto Rico and should be evaluated under local conditions which are similar to those of vast areas in the humid tropics. The traditional method of evaluating new grasses by growing them in small plots and cutting, weighing and analyzing the forage produced, is simple and inexpensive and provides valid information on their productivity under cutting management. However, such data often do not provide reliable information on the performance of these grasses under actual grazing conditions, which include more frequent harvesting, selective grazing by the cattle, trampling of the forage, soil compaction, and voiding of urine and feces.

On the other hand, it is very costly and usually impractical to evaluate numerous grasses in large scale grazing experiments in which their capacity to produce milk or meat as well as their carrying capacity are determined.

There is, therefore, a great need for a simple, inexpensive research technique suited to determining the performance of rather large numbers of grasses under actual grazing conditions. Vicente-Chandler, Rodríguez and Abruña (9) devised such a system, and used it successfully to determine the effect of grazing heights and intervals on the performance of Pangola grass. Rodríguez and Silva (5) also used this method in a similar study with Star grass.

This paper presents the results of an experiment in which the yields of dry forage produced by four tropical grasses were determined under grazing management using the technique developed by Vicente-Chandler, Rodríguez and Abruña (9).

\section{MATERIALS AND METHODS}

The experiment was conducted over a 2-year period (September 1, 1974 to August 30, 1976) at the Corozal Substation. Elevation is about $200 \mathrm{~m}$ and average annual temperature is about $25^{\circ} \mathrm{C}$ with seasonal variations of about $4^{\circ} \mathrm{C}$. The soil is Corozal clay (Aquic Tropudults) on a $20 \%$ slope.

The four grasses (table 1) were replicated five times in a randomized block design using $10 \mathrm{~m}^{2}$ plots. A solid stand of the grasses was established 
in the corresponding plots and the soil was limed to about pH 5.5 A 15-510 fertilizer was applied at the rate of 2.2 metric tons/ha/yr divided in four equal applications.

The plots, each surrounded by a barbed and chicken wire fence to prevent cattle from grazing adjacent plots, were grazed at 3 to 4 week intervals, One Holstein heifer was confined in each plot until the grass had been grazed down to a height of about $15 \mathrm{~cm}$, which took 1 or 2 days.

The forage consumed by the cattle in each plot at each grazing was determined as follows:

Five pairs of sampling areas, representative of the forage in the plot, were located in each plot before each grazing round. The forage in one of each pair of sampling areas (0.4 m square) was cut to a height of $5 \mathrm{~cm}$ from the ground, dried and weighed. These data provided an estimate of the quantity of forage available to the grazing cattle. After grazing, the forage in the remaining five sampling areas was also cut to a $5 \mathrm{~cm}$ height, dried and weighed. These data provided an estimate of the forage remaining after grazing. The forage consumed by the grazing cattle was calculated by substracting the quantity of forage remaining in the plots after grazing from that available before grazing. This procedure was repeated at each grazing over a 2-year period, providing a total of over 25 yield determinations in each plot.

\section{RESULTS AND DISCUSSIONS}

Rainfall during the course of the experiment is shown in the following tabulation:

$\begin{array}{lrr}\text { Month } & \begin{array}{r}\text { First } \\ \text { year } \\ (\mathrm{mm})\end{array} & \begin{array}{r}\text { Second } \\ \text { year } \\ (\mathrm{mm})\end{array} \\ \text { September } & 238 & 183 \\ \text { October } & 488 & 201 \\ \text { November } & 250 & 173 \\ \text { December } & 149 & 280 \\ \text { January } & 154 & 97 \\ \text { February } & 21 & 119 \\ \text { March } & 141 & 130 \\ \text { April } & 56 & 145 \\ \text { May } & 53 & 78 \\ \text { June } & 24 & 35 \\ \text { July } & 74 & 35 \\ \text { August } & 178 & \underline{96} \\ \quad \text { Total } & \underline{1,826} & \underline{1,672}\end{array}$

Annual rainfall was similar during both years, averaging $1,749 \mathrm{~mm} /$ year. Monthly rainfall ranged from as low as $21 \mathrm{~mm}$ to as high as 488 $\mathrm{mm}$. During both years, rainfall was low during a consecutive 4-month period. 
Table 1 shows that there were no significant differences in either year or in the average of both years in the productivity of Pangola, Signal, Tanner or Transvala grasses. It should be noted that Tanner grass may be toxic to cattle as shown by Soldevila et al. (6).

The yields obtained in this experiment with Pangola, Signal and Tanner were compared with those obtained in a nearby large grazing experiment by Caro-Costas (1) which included these grasses. In the large scale grazing experiment, Pangola, Tanner and Signal grasses produced similar weight gains averaging $823 \mathrm{~kg} / \mathrm{ha} / \mathrm{yr}$ while in the experiment discussed in this paper these three grasses produced similar yields of dry forage.

Also, forage yields obtained in the small grazed plots used in the experiment described in this paper compare with those obtained in the

TABLE 1.-Productivity of four grasses under grazing management in the humid hill region of Puerto Rico

\begin{tabular}{|c|c|c|c|c|}
\hline \multirow{2}{*}{ Grass } & \multicolumn{3}{|c|}{$\begin{array}{l}\text { Yield of dry forage } \\
(\mathrm{kg} / \mathrm{ha} / \mathrm{yr})\end{array}$} & \multirow{2}{*}{$\begin{array}{c}\text { Adjacent } \\
\text { large } \\
\text { grazing } \\
\text { experiment }\end{array}$} \\
\hline & $\begin{array}{l}\text { First } \\
\text { year }\end{array}$ & $\begin{array}{l}\text { Second } \\
\text { year }\end{array}$ & Average & \\
\hline Pangola (Digitaria decumbens) & $10,070^{2} \mathrm{a}$ & $10,580 \mathrm{a}$ & 10,330 & 12,170 \\
\hline Signal (Brachiaria brizantha) & 8,660 a & 11,140 a & 9,900 & 12,980 \\
\hline Tanner (Brachiaria radicans) & 9,330 a & $12,730 \mathrm{a}$ & 11,030 & 11,370 \\
\hline Transvala grass & $11,070 \mathrm{a}$ & $10,160 \mathrm{a}$ & 10,620 & - \\
\hline
\end{tabular}

${ }^{1}$ From Caro-Costas (1).

${ }^{2}$ Values followed by the same letter do not differ significantly at the $5 \%$ probability level, (Duncan's new multiple range test).

adjacent large grazing experiment (table 1). For this comparison, the total digestible nutrients produced/ha/yr in the large grazing experiment were calculated from the number of head carried per hectare, their weight and the weight gains made. It was assumed that $0.8 \mathrm{~kg}$ of total digestible nutrients is required daily for maintenance per $100 \mathrm{~kg}$ of liveweight and that $3.53 \mathrm{~kg}$ is needed for each $\mathrm{kg}$ of weight gain. The dry forage consumed by the grazing cattle was then calculated from these data assuming that the ingested forage was 55\% digestible as indicated by the experiments summarized by VicenteChandler et al. (7).

Results of these calculations are shown in the last column of table 1. Pangola, Tanner and Signal grasses produced an average of $12,178 \mathrm{~kg}$ of dry forage/ha/yr in the large grazing experiment, which checks rather well with an average of $10,420 \mathrm{~kg} / \mathrm{ha} / \mathrm{yr}$ produced by these grasses in the experiment discussed in this paper. Yields in the small enclosures were about $14 \%$ lower on the average, which may be explained by more 
loss of forage due to trampling when one heifer was confined in a $10 \times$ $10 \mathrm{~m}$ plot which is equivalent to having 100 heifers grazing on 1 ha.

These results indicate that the simple techniques used to evaluate grasses under grazing conditions in this experiment and in previous experiments by Vicente-Chandler, Rodríguez and Abruña (9) and by Rodríguez and Silva (5) constitute a valid method for determining the productivity of grasses under actual grazing conditions.

\section{RESUMEN}

Se determinó el forraje producido por cuatro gramíneas pastadas en parcelas de $10 \times 10 \mathrm{~m}$ repetidas cinco veces en un experimento de 2 años en Corozal.

La producción de las distintas gramíneas en $\mathrm{kg}$ de forraje seco/ha y año fue como sigue: Pangola-10,330; Signal-9,900; Tanner11,030; y Transvala-10,620. No hubo diferencia significativa en producción entre estos pastos.

La producción de forraje por los pastos Signal, Tanner y Congo fue comparable a la obtenida en un experimento de pastoreo adyacente con parcelas de 0.4 ha, lo cual confirma la validez de la técnica de pastoreo con parcelas pequeñas utilizadas en este experimento para evaluar el potencial de las gramíneas bajo condiciones de pastoreo.

\section{LITERATURE CITED}

1. Caro-Costas, R. 1979, Weight gains of cows fed on five grass pastures intensively managed in the humid hill region of Puerto Rico. J. Agri., Univ. P.R. 64 (1):

2. - Abruña, F., and Vicente-Chandler, J., 1973. Comparison of heavily fertilized Pangola and Star grass pastures under humid tropical conditions, Agron. J., 65: 132-33.

3. -, Vicente-Chandler, J., and Figarella, J. 1965., Productivity of intensively managed pastures of 5 grasses on steep slopes in the humid mountains of Puerto Rico, J. Agri. Univ. P.R., 49 (1): 99-111.

4. - - - and Abruña, F., 1976. Comparison of heavily fertilized Congo, Star and Pangola grass pastures in the humid mountain region of Puerto Rico, J. Agri. Univ. P.R., 60 (2): 179-85.

5. Rodriguez, J and Silva, S., 1975, Effect of two heights and three intervals of grazing on stand of heavily fertilized Star grass pasture, J. Agri. Univ. P.R., 54 (3): 215-18.

6. Soldevila, M., Green, J., Sotomayor-Ríos, A., Arroyo-Aguilú, J. A., y Vélez Santiago, J., 1979. Alimentación de novillas Holstein en crecimiento exclusivamente con pastos Tanner, Pangola, Milanjiana, Guinea y Signal, durante las cuatro estaciones del año. Publ. 127, Esta. Exp. Agri., Univ. P.R., (In press).

7. Vicente-Chandler, J., Abruña, F., Caro-Costas, R., Figarella, J., Silva, S., and Pearson, R. W., 1974. Intensive Grassland Management in the Humid Tropics of Puerto Rico, Bull. 233, Agri. Exp. Stn. Univ, P.R.

8. - Caro-Costas, R., Pearson, R. W., Abruña, F., Figarella, J., and Silva, S., 1964. The intensive management of tropical forages in Puerto Rico, Bull. 187, Agri. Exp. Stan.

9. - Rodríguez, J., and Abruña, F., 1972. Effects of two heights and three intervals of grazing on the productivity of a heavily fertilized Pangola grass pasture, J. Agri. Univ. P.R., 56 (2): 110-14. 